\title{
Mother's Behavior In Caring For Low Birth Weight Babies (LBW) At Home
}

\author{
Ramenia M Lubis \\ Sumatera Utara Faculty Of Nursing \\ E-mail: ramenialubis@gmail.com
}

\begin{abstract}
Behavior of caring for babies with low birth weight (LBW) is a reaction or response to the condition of LBW babies which is divided into three domains, namely knowledge, attitudes and actions. Good behavior of mothers in caring for infants with LBW will have an impact on reducing mortality and morbidity rates for infants and toddlers. Descriptive research was conducted with the aim of knowing the level of knowledge, attitudes and actions of mothers in caring for LBW babies at home. The sample in this study were 30 mothers who had LBW babies aged 1 year, residing in Medan and had been taking care of them at home. This research uses purposive sampling technique. The results showed that the mother's behavior in caring for LBW babies at home for the majority knowledge domain was good (100\%), for the attitude domain the majority is positive (100\%) and for the action domain the majority is good (100\%). It is concluded that knowledge, attitudes, actions in this study are in line with behavioral theory. It is recommended to conduct research by exploring the factors that support the formation of a good level of knowledge, positive attitudes and good actions.
\end{abstract}

Keywords: LBW Care, Knowledge, Attitude, Action

\section{Introduction}

Low Birth Weight (LBW) is a condition where the baby's birth weight when weighed in the first hour of birth is less than 2,500 grams. Babies with low birth weight have a tendency to be prone to infections and complications (Health Profile, 2013). This is also supported by research which states that babies with low birth weight are included in the category of high risk babies, because babies born with LBW are very vulnerable to various disorders in their body systems such as respiratory disorders, nutritional disorders, and are susceptible to infections. This is due to the weak immune system of babies with low birth weight (Tjipta, 2004). Until now, low birth weight (LBW) is still a problem

public health in many countries, because it is considered to be one of the factors causing infant mortality. According to WHO (1992) Low Birth Weight (LBW) is also closely related to morbidity, stunted growth and cognitive development, and chronic disease in later life (Pramono, 2014).

WHO and Unicef (2004) stated that the number of LBW in developing countries (16.5\%) is more than 2 times the number of LBW in developed countries. There are 20 million babies born in the world with Low Birth Weight (LBW) and 95\% of this number are in many developing countries. The results of Riskesdas (2013), nationally the percentage of babies with low birth weight is $6.37 \%$ (474 of 7439 babies), this number then increases the number of infants with low body weight (Pramono, 2014). The number of babies born with low birth weight in 2011-2012 at Haji Adam Malik Hospital were 178 babies, where in 2011 there were 86 babies and in 2012 increased to 92 babies (Krishnan, 2013).

The length of time a LBW baby is treated in the hospital is not determined with certainty, but the length of treatment is determined by the baby's ability to adapt to its environment, such as no more breathing problems, stable body temperature and good sucking and swallowing reflexes. Before the baby goes home and is then treated at home, the baby does not suffer from respiratory problems anymore and does not need oxygen and drugs given through a vein or infusion (Proverawati \& Ismawati, 2010).

After the baby returns home, the parents, especially the mother, must be physically and psychologically able and ready to take care of the baby at home. Mothers must be able to master how to breastfeed properly, how to bathe, care for the umbilical cord, change diapers, give breast milk and complementary feeding (PASI), as well as maintain cleanliness and an optimal environment for baby's growth and development. Mothers must be confident and dare to take care of their own babies, because by taking care of their babies there will be contact to create a bond between mother and baby (Proverawati \& Ismawati, 2010). The care carried out by mothers for LBW babies greatly affects the quality 
and survival of the babies and if the mothers do not do it properly it can cause infection, malnutrition and death of LBW babies.

\section{Method}

The research design used in this study is descriptive, that is, a study conducted to describe or describe a phenomenon that occurs in society. The design of this study was to identify the mother's behavior in caring for LBW babies.

The instrument used in this study was a questionnaire containing statements about the care of LBW infants. At the beginning of the instrument contains demographic data of the respondent, namely, the name, age and last education of the respondent.

Instruments to measure the level of knowledge, attitudes and actions of mothers in caring for LBW babies at home, each consisting of 9 statements with the answer choices for knowledge are True $=1$, False $=0$. The answer choices for the attitude questionnaire are Strongly Agree $(\mathrm{SS})=4$, Agree $(\mathrm{S})=3$, Disagree $(\mathrm{TS})=2$, Strongly Disagree $(\mathrm{STS})=1$ and the answer choices for the action questionnaire are Always $(\mathrm{SI})=4$, Often $(\mathrm{Sr})=3$, Sometimes $(K)=2$, Never $(T P)=1$.

The data that has been collected will be processed manually, namely editing the data (editing), which is checking the completeness and then coding (coding), which is changing the data in the form of letters into data in the form of numbers. This is done to facilitate the entry (entry) of data into the computer. Then the data is entered into the computer (entry). Before the data is processed, a cleaning process is carried out, namely re-checking the data that has been entered to see whether there are errors in entering the data. , the action is made in the form of a frequency distribution table and percentage.

\section{Analysis And Results}

\subsection{Research Results}

\section{a. Characteristics Of Respondents}

Below will be described the frequency distribution and the percentage of respondents' characteristics. The number of respondents in this study were 30 people. The characteristics of the respondents described are age and education. The results showed that the age group was $26-35$ years (76.6\%), 17-25 years (16.7\%), and the age group $36-45$ years (6.7\%). The highest education level of the respondents is SMA (50.0\%) and the least is SD (3.3\%). For more details, the percentage of respondents' characteristics can be seen in table 1 below.

Table 1. Frequency distribution and percentage of respondent characteristics $(n=30)$

\begin{tabular}{ccc}
\hline $\begin{array}{c}\text { Characteristics } \\
\text { Age Late Teen }\end{array}$ & Frequency & Percentage (\%) \\
Early Adult & 5 & 16.7 \\
Late Adult & 23 & 6.7 \\
Education & 2 & 3.3 \\
Elementary & 1 & 33.3 \\
School & 10 & 50.0 \\
Middle & 15 & 6.7 \\
School D3 & 2 & 6.7 \\
S1 & 2 & \\
\hline
\end{tabular}

\section{b. Knowledge, attitudes, and actions of mothers in caring for LBW babies}

From the results of data collection, it was found that all respondents had good knowledge in caring for LBW babies (100\%). Similar to the attitude of mothers in caring for LBW babies, all respondents have a positive attitude (100\%). Likewise with the actions of mothers in caring for LBW babies, all respondents have good actions (100\%). The frequency distribution table and the percentage level of knowledge, attitudes and actions can be seen in table 2 below. 
Table 2 Distribution of Knowledge Levels, Attitudes and Actions of Mothers in Caring for LBW Babies at Home ( $\mathrm{n}=30)$

\begin{tabular}{llcc} 
No $\quad$ Variable & Frequency & Percentage (\%) \\
\hline $\mathbf{1}$ & Knowledge Good Enough & 30 & 100 \\
& Not enough & - & - \\
& & - & \\
& & & 100 \\
& Attitude & 30 & - \\
& Positive Negative & - & 100 \\
& Action & & - \\
\hline
\end{tabular}

Knowledge

All respondents have a good level of knowledge (100\%). If viewed in more detail the respondents' answers on the questionnaire sheet, not all respondents answered correctly in every statement. There are 3 statements where all respondents answered correctly, namely statement number 6 about changing diapers, number 8 about washing hands, and statement number 9 about washing or boiling baby equipment. The frequency distribution table and percentage can be seen in table 3 below.

Table 3 Frequency Distribution of Mother's Knowledge in Caring for LBW Babies at Home $(n=30)$

\begin{tabular}{llrrrr}
\hline \multirow{2}{*}{ No } & Statement & \multicolumn{2}{c}{ Right } & \multicolumn{2}{c}{ Wrong } \\
\cline { 3 - 6 } & & $\mathrm{F}$ & $\%$ & $\mathrm{f}$ & $\%$ \\
\hline 1 & Frequency of breastfeeding & 29 & 96.7 & 1 & 3.3 \\
2 & Expressing breast milk through a spoon & 24 & 80.0 & 6 & 20.0 \\
3 & Prevents body heat loss & 28 & 93.3 & 2 & 6.7 \\
4 & Kangaroo method & 27 & 90.0 & 3 & 10.0 \\
5 & Keeping baby warm & 28 & 93.3 & 2 & 6.7 \\
6 & Changing a wet diaper or cloth & 30 & 100 & - & - \\
7 & Keeping sick family members away & 29 & 96.7 & 1 & 3.3 \\
8 & Wash your hands to prevent infection & 30 & 100 & - & - \\
9 & Cleaning or boiling baby utensils & 30 & 100 & - & - \\
\hline
\end{tabular}

Attitude

From the results of data collection, it was found that all respondents had a good attitude in caring for LBW babies (100\%). The attitude of the respondents in caring for LBW infants was assessed based on the respondents' answers on the questionnaire sheet. If seen in the frequency distribution table and the percentage of mothers' attitudes in caring for LBW babies, not all respondents gave a positive attitude towards all statements. The statement answered strongly agree was statement number 9 about cleaning or washing baby equipment (56.7\%). The most disagreed answers were found in statements number 2 and (20.0\%) and the least answered with a strongly agree answer (16.7\%). Mother's attitude in caring for LBW babies can be seen in table 5.3 below.

Table 4 Distribution of Frequency and Percentage of Mothers' Attitudes in Caring for LBW Babies at Home ( $\mathrm{n}=30$ )

\begin{tabular}{|c|c|c|c|c|c|c|c|c|c|}
\hline \multirow[t]{2}{*}{ No } & \multirow[t]{2}{*}{ Statement } & \multicolumn{2}{|c|}{ SS } & \multicolumn{2}{|c|}{$S$} & \multicolumn{2}{|c|}{ TS } & \multicolumn{2}{|c|}{ STS } \\
\hline & & $f$ & $\%$ & $\mathrm{~F}$ & $\%$ & $f$ & $\%$ & $\mathrm{~F}$ & $\%$ \\
\hline 1 & Frequency of breastfeeding & 6 & 20.0 & 22 & $73 \cdot 3$ & 2 & 6.7 & - & - \\
\hline 2 & Breastfeeding via spoon & 5 & 16.7 & 19 & 63.3 & 6 & 20.0 & - & - \\
\hline 3 & Prevents body heat loss & 6 & 20.0 & 21 & 70.0 & 3 & 10.0 & - & - \\
\hline 4 & Kangaroo method & 7 & 23.3 & 19 & 63.3 & 4 & $13 \cdot 3$ & - & - \\
\hline 5 & Keeping baby warm & 6 & 20.0 & 23 & 76.7 & 1 & 3.3 & - & - \\
\hline 6 & $\begin{array}{l}\text { Changing diapers or cloths } \\
\text { Wet }\end{array}$ & 11 & 36.7 & 19 & 63.3 & - & - & - & - \\
\hline 7 & $\begin{array}{l}\text { Keeping family members away } \\
\text { Sick }\end{array}$ & 14 & 46.7 & 15 & 50.0 & 1 & 3.3 & - & - \\
\hline 8 & $\begin{array}{l}\text { Wash your hands to prevent } \\
\text { Infection }\end{array}$ & 10 & 33.3 & 20 & 66.7 & - & - & - & - \\
\hline
\end{tabular}




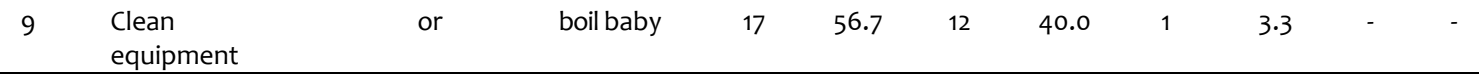

\section{Mother's Actions in Caring for LBW Babies}

From the results of data collection, it was found that all respondents had good actions (100\%). However, if you look at the respondents' answers to each statement of action, not all respondents do every statement of the action. The highest percentage of answers is always statement number 9, which is about washing baby equipment for 23 people (76.7\%). The highest percentage of answers was never found in statement number 2 about breastfeeding through a spoon for 9 people (30.0\%). The distribution of the frequency and percentage of maternal actions in caring for LBW babies can be seen in table 5.4 below.

Table 5 Distribution of Frequency and Percentage of Mother's Actions in Caring for LBW Babies at Home $(n=30)$

\begin{tabular}{|c|c|c|c|c|c|c|c|c|c|}
\hline \multirow[t]{2}{*}{ No } & \multirow[t]{2}{*}{ Statement } & \multirow{2}{*}{$\frac{S L}{f}$} & \multicolumn{2}{|c|}{ SR } & \multicolumn{2}{|r|}{ KK } & \multicolumn{2}{|c|}{ TP } & \multirow[b]{2}{*}{$\%$} \\
\hline & & & $\%$ & $\mathrm{~F}$ & $\%$ & $\mathrm{~F}$ & $\%$ & $f$ & \\
\hline 1 & frequency of breastfeeding) & 7 & 23.4 & 17 & 56.7 & 6 & 20.0 & - & - \\
\hline 2 & $\begin{array}{l}\text { Expressing breast milk through } \\
\text { spoon }\end{array}$ & 3 & 10.0 & 3 & 10.0 & 15 & 50.0 & 9 & 30.0 \\
\hline 3 & $\begin{array}{lll}\text { Prevent } & \text { lost } & \text { hot } \\
\text { body } & & \end{array}$ & 6 & 20.0 & 20 & 66.7 & 1 & 3.3 & 3 & 10.0 \\
\hline 4 & Kangaroo method & 5 & 16.7 & 8 & 26.7 & 10 & $33 \cdot 3$ & 7 & 23.3 \\
\hline 5 & $\begin{array}{l}\text { Maintain warmth } \\
\text { baby }\end{array}$ & 8 & 26.7 & 19 & 63.3 & 1 & $3 \cdot 3$ & 2 & 6.7 \\
\hline 6 & $\begin{array}{l}\text { Changing diapers or cloths } \\
\text { wet one }\end{array}$ & 17 & 56.7 & 13 & 43.3 & - & - & - & - \\
\hline 7 & $\begin{array}{l}\text { Keep members away family } \\
\text { sick }\end{array}$ & 14 & 46.7 & 15 & 30.0 & 1 & 3.3 & - & - \\
\hline 8 & $\begin{array}{l}\text { Wash hand } \\
\text { prevent infection }\end{array}$ & 13 & 43.3 & 17 & 56.7 & - & - & - & - \\
\hline 9 & $\begin{array}{l}\text { Cleaning or boiling } \\
\text { baby equipment }\end{array}$ & 23 & 76.7 & 6 & 20.0 & 1 & 3.3 & - & - \\
\hline
\end{tabular}

\section{Conclusion}

The results of research that has been conducted on "Maternal Behavior in Caring for Low Birth Weight Babies (LBW) at Home" conducted in May-June 2016 can be concluded that the majority of mothers who have LBW babies have high school education (50.0\%) and are aged 26-35 years (early adulthood) $(76.6 \%)$. In accordance with the research objectives, to identify the knowledge, attitudes and actions of mothers in caring for LBW babies at home. It was found that the knowledge of mothers in caring for LBW babies at home was good. Mother's attitude in caring for LBW babies at home is positive. And the mother's actions in caring for LBW babies at home are good. So it can be concluded that the results of this study are in accordance with the behavioral theory of Notoadmodjo (2010).

\section{References}

Cut, Fitriyani. 2016. The experience of postpartum mothers in carrying out lactation management in infants with low birth weight in Delitua District, Deli Serdang Regency. USU Digital Libraries.

http://repository.usu.ac.id/bitstream/123456789/55532/3/Chapter\%2ollI-V.pdf

Garini, Widyawati. 2002. Effect of VCD intervention with Attachment Infant Care Method (MPBL) on Knowledge of Mothers of Low Birth Weight Babies (LBW) at Ciawi Regional General Hospital, Bogor Regency, West Java, 2002.http://lib.ui.ac.id/abstrakpdfdetail.jsp?id=77949\&location=lokal

Giri, Made K, W., Suryani, N., Murdani, K, P. (Relationship of Mother's Knowledge and Attitudes About Breastfeeding and Exclusive Breastfeeding with Nutritional Status of Toddlers Age 6-24 Months (In Kampung Kajanan Village, Buleleng District. http://jurnal.pasca.uns.ac.id

Ministry of Health. 2013. Indonesian Health Profile. Jakarta: Ministry of Health RIhttp://www.depkes.go.id/resources/download/pusdatin/profile-health-indonesia/profile-health-indonesia2013.pdf. 
Ministry of Health. 2015. Strategic Plan of the Ministry of Health 2015-2019. Jakarta: Ministry health RI http://www.depkes.go.id/resources/download/info-publik/Renstra-2015.pdf

Ministry of Health. 2013. Basic Health Research. Jakarta: Ministry of health $\quad$ RI.

Ministry of Health. 2013. Health Profile of North Sumatra. Medan: Ministry of Health of North Sumatra.

Hanum, et al. 2014. Overview of Infant Morbidity with Low Birth Weight (LBW) in the Perinatology Room of Arifin Achmad Hospital Pekanbaru. Riau University.

Krishnan, M. 2013. Birth Profile of Babies with Low Birth Weight (LBW) at Haji Adam Malik General Hospital Medan in 2011-2012. University of Northern Sumatra.http://repository.usu.ac.id/handle/123456789/42691

Maryunani, A \& Nurhayati. 2009. Emergency and Complicated Care for Neonates. Jakarta: TEAM.

Notoadmodjo, S. 2010. Health Promotion Theory and Applications. Jakarta: Rineka Cipta Notoatmodjo, S. 2012. Health Research Methodology. Jakarta: Rineka Cipta Nursalam. 2008. Concept and Application of Nursing Research Methodology.

Jakarta: Salemba Medika

Pantiawati, I. 2010. Babies with Low Birth Weight (LBW). Yogyakarta: Nuha Medika.

Pramono, Mochamad Setyo \& Paramita, A. Patterns of Occurrence and Determinants of Babies with Low Birth Weight (LBW) in Indonesia. Indonesia.

Proverawati, A \& Ismawati, C. 2010. Low Birth Weight. Yogyakarta: Nuha Medika.

Rahayu, Ary Oktora Sri. 2011. Relationship between Knowledge and Mother's Attitude towards Follow-up Care for PrematureBabiesfrom RSUD. Dr. Pirngadi Medan in 2011.

Rahayu, Ary Oktora Sri. 2011. Relationship between Knowledge and Mother's Attitude towards Follow-up Care for Premature Babies from RSUD. Dr. Pirngadi Medan in 2011.

Sutomo, Omo. 2002. Mothers' behavior in caring for low birth weight babies: a case study in district Bogor year 2002. http://lib.ui.ac.id/abstrakpdfdetail.jsp?id=103350\&location=lokal \%20CITY\%20BANDUNG.

Tjipta, Guslihan Dasa. 2004. High-Risk Babies. USU Digital .

Wawan, A \& Dewi. 2010. Theory and Measurement of Knowledge, Attitudes, and Human Behavior. Yogyakarta: Nuha Medika 